\title{
Dolphin whistles can be useful tools in identifying units of conservation
}

Elena B. Papale ${ }^{1,2^{*}}$, Marta A. Azzolin², Irma Cascão ${ }^{3}$, Alexandre Gannier ${ }^{4}$, Marc O. Lammers ${ }^{5,6}$, Vidal M. Martin ${ }^{7}$, Julie N. Oswald ${ }^{8}$, Monica Perez-Gill, ${ }^{7}$ Rui Prieto ${ }^{3,9}$, Mónica A. Silva ${ }^{3,10}$, Marco Torri ${ }^{1}$ and Cristina Giacoma ${ }^{2}$

\begin{abstract}
Background: Prioritizing groupings of organisms or 'units' below the species level is a critical issue for conservation purposes. Several techniques encompassing different time-frames, from genetics to ecological markers, have been considered to evaluate existing biological diversity at a sufficient temporal resolution to define conservation units. Given that acoustic signals are expressions of phenotypic diversity, their analysis may provide crucial information on current differentiation patterns within species. Here, we tested whether differences previously delineated within dolphin species based on i) geographic isolation, ii) genetics regardless isolation, and iii) habitat, regardless isolation and genetics, can be detected through acoustic monitoring. Recordings collected from 104 acoustic encounters of Stenella coeruleoalba, Delphinus delphis and Tursiops truncatus in the Azores, Canary Islands, the Alboran Sea and the Western Mediterranean basin between 1996 and 2012 were analyzed. The acoustic structure of communication signals was evaluated by analyzing parameters of whistles in relation to the known genetic and habitat-driven population structure.

Results: Recordings from the Atlantic and Mediterranean were accurately assigned to their respective basins of origin through Discriminant Function Analysis, with a minimum 83.8\% and a maximum 93.8\% classification rate. A parallel pattern between divergence in acoustic features and in the genetic and ecological traits within the basins was highlighted through Random Forest analysis. Although it is not yet possible to establish a causal link between each driver and acoustic differences between basins, we showed that signal variation reflects fine-scale diversity and may be used as a proxy for recognizing discrete units.

Conclusion: We recommend that acoustic analysis be included in assessments of delphinid population structure, together with genetics and ecological tracer analysis. This cost-efficient non-invasive method can be applied to uncover distinctiveness and local adaptation in other wide-ranging marine species.
\end{abstract}

Keywords: Communication signals, Acoustic divergence, Geographic variability, Phenotypic diversity, Cetaceans

\footnotetext{
* Correspondence: elena.papale@cnr.it

'Institute for the Study of Anthropic Impacts and Sustainability in the Marine Environment (CNR-IAS), unit of Capo Granitola, National Research Council, Via del Mare 3, 91021 Campobello di Mazara, TP, Italy

${ }^{2}$ Life Sciences and Systems Biology Department, University of Torino, Via Accademia Albertina 13, 10123 Torino, Italy

Full list of author information is available at the end of the article
}

(C) The Author(s). 2021 Open Access This article is licensed under a Creative Commons Attribution 4.0 International License, which permits use, sharing, adaptation, distribution and reproduction in any medium or format, as long as you give appropriate credit to the original author(s) and the source, provide a link to the Creative Commons licence, and indicate if changes were made. The images or other third party material in this article are included in the article's Creative Commons licence, unless indicated otherwise in a credit line to the material. If material is not included in the article's Creative Commons licence and your intended use is not permitted by statutory regulation or exceeds the permitted use, you will need to obtain permission directly from the copyright holder. To view a copy of this licence, visit http://creativecommons.org/licenses/by/4.0/ The Creative Commons Public Domain Dedication waiver (http://creativecommons.org/publicdomain/zero/1.0/) applies to the data made available in this article, unless otherwise stated in a credit line to the data. 


\section{Background}

Distinguishing unambiguous groupings of organisms, or 'units', that are relevant to the proper implementation of management actions is still a matter of debate [1, 2]. In order to be applied to a wide range of taxa, a contextbased flexible definition is required, given that different approaches may work more efficiently than others in relation to the situational circumstances [3].

A Unit of Conservation (UC) can be defined as a segment within a species to be considered distinct for conservation purposes [4]. The most prominent and discussed conservation units are Evolutionarily Significant Units (ESUs) and Management Units (MUs). The ESU criteria were first proposed by Rider [5] and subsequently reformulated to integrate information about genetic distinctiveness with data regarding adaptive variation based on ecological features [6, 7]. Management Units are considered as distinct units at a smaller scale compared to ESUs, demographically independent and important for ensuring long-term persistence of species [4]. However, genetic differences identified at the mtDNA and microsatellites levels, that have influenced the majority of the management actions carried out in the last decades, may fail in accurately defining units for conservation purposes over a short-time scale. Due to the difficulty in operationally applying the concept, several approaches have been considered to identify distinct units, such as ecological tracers and life-history parameters [2].

Recent developments include investigations into how variation in acoustic signals may be a line of evidence supporting the significance for conservation and management of different populations [8]. Variation can occur over short time scales through adaptive environmental diversification that fosters isolation and can drive phenotypic evolution [8]. Differences in the characteristics of acoustic signals can be determined by genetic factors [9-11], or support genetic differences, and therefore may be informative for reconstructing lineage histories [12]. Nevertheless, communication signals are adaptive and selection favours characteristics that enhance transmission quality under local conditions by reducing their masking and attenuation [13]. Therefore, selective pressures deriving from habitat characteristics can differentially and independently act on some individual traits of the signal $[14,15]$. This is the case in a number of animal taxa such as insects [16], frogs [12, 17], songbirds $[18,19]$, primates [20-22], and marine mammals [23, 24]. Furthermore, social and cultural inheritance and gene-culture co-evolution have been suggested to play an important role in the evolution of species behaviour, such as vocalizations [25]. Finally, morpho-physiological constraints, such as those related to body size, are known to influence some frequency parameters [26].
Even though vocal diversity is high both among and within some animal species, vocal patterns have been used to reconstruct hypotheses of evolutionary histories: geographic distances and genetic variation among gibbon populations are strongly correlated with variation in song structure [27, 28], as well as between populations of Neotropical singing mice [29, 30]. However, the use of acoustic signals as a proxy for genetic divergence is still a matter of debate, particularly in species capable of vocal learning [31]. The process of vocal learning (the ability to modify or acquire acoustic signals through experience, imitation, cultural transmission or association to context) could influence the characteristics of acoustic signals. Evidence for vocal learning has been well documented, especially for birds [32-35] and cetaceans [36, 37]. As suggested by Brumm \& Naguib [19] and Janik [38], learning enables a rapid adjustment of the signals to the acoustic properties of the local habitat, as well as cultural evolution and ontogenetic development [10]. Therefore, the contribution of genetics with the aim of distinguishing units can be difficult to delineate when groups overlap in the same areas.

In dolphins, intra-specific variation in the characteristics of tonal whistles has been described at macro- and micro-geographic scales [39-43] among others. Whistles are tonal signals used by many delphinid species for intra- and inter- specific communication. Many factors cause whistle variability. Whistle acoustic parameters vary independently under many local selective pressures [44], either ecological or cultural. Dolphins can also learn to develop context-specific acoustic structures [45] and individual-specific frequency modulation in signature whistles [46, 47]. Some frequency parameters of tonal signals are under morphological constraints and have been shown to contain the lowest amount of intraspecific variation for many species [48]. Frequency parameters of tonal signals have low variability and may be good candidates for determining divergence [49]. Nevertheless, dolphins' whistle parameters have never been used for evaluating whether characteristics of acoustic signals can predict units of conservation (UCs).

Determining discrete units of conservation for dolphins can be an arduous task [50], given the difficulty of studying cetacean genetic population structure and the cost of analysis. However, due to the different pressure of local threats, such as fishing activity, pollution and marine traffic, on coastal and pelagic areas, it is crucial to define the borders of distinct UCs. Furthermore, since some dolphins species, notably bottlenose, striped and common dolphins, are considered Data Deficient by the International Union for the Conservation of Nature in European waters (and vulnerable or endangered at the Mediterranean level), it is critical to investigate which time-scale is suitable to consider for adequate management. 
Acoustics may provide an additional source of data that can help the understanding of discrepancies through space and over time of those discrete units [51]. Here, we investigate whether the characteristics of time-frequency contours can help identify units of conservation in species capable of vocal learning. We examine the patterns of variation in whistle time-frequency characteristics in three dolphin species, phylogenetically related [52] and all widespread both in the Mediterranean and in the Atlantic Oceans: bottlenose dolphins (Tursiops truncatus), short-beaked common dolphins (Delphinus delphis) and striped dolphins (Stenella coeruleoalba). In detail, we examine if whistles can be used to verify the possible existence of UCs among a poorly studied area by comparing groups defined according to three different criteria. Specifically, we tested:

1. the effect of geographic isolation;

2. the effect of genetics, regardless the isolation;

3. the effect of habitat, regardless isolation and genetics

\section{Methods}

\section{The selected model}

Principal features for each sampling area/species are summarized in Table 1.

\section{Population structures}

Bottlenose dolphins - Genetic studies have shown a limited amount of gene flow between Mediterranean and Atlantic populations of bottlenose dolphins [54, 61]. According to Natoli et al. [54], a very recent division is suggested for the boundary that divides the North Atlantic samples from the western Mediterranean Sea. Within the Atlantic, comparisons between the Azores and the Canaries have shown that these populations are genetically similar [55]. However, a habitat-driven population structure has been recently identified [61], and the presence of some resident individuals in the Azores area [62] might generate reproductive isolation between pods. Within the Mediterranean, Natoli et al. [54] examined nine microsatellite loci and mtDNA control region founding a divergence across the Mediterranean with boundaries possibly corresponding to the AlmerianOran front and the Siculo-Tunisian front. Also, a distinction among Spanish and Tyrrhenian bottlenose dolphins, probably related to the habitat features that define patterns of movement, was identified by Moore [63].

Short-beaked common dolphins - Even if, mtDNA data suggested gene flow mediated by females from across the Gibraltar Strait [56], the Alboran population showed significant genetic differentiation compared to

Table 1 Summary of the model species considered in the study. For each species, the geographic region, location, and genetic situation has been shown

\begin{tabular}{|c|c|c|c|}
\hline Species & GeographicRegion & Location & Genetics \\
\hline \multirow[t]{6}{*}{ Bottlenose dolphin } & \multirow[t]{2}{*}{ Atlantic Ocean } & Azores Islands & \multirow[t]{2}{*}{ Considered as a single Atlantic population [53] } \\
\hline & & Canary Islands & \\
\hline & \multirow[t]{4}{*}{ Mediterranean Sea } & Tyrrhenian Sea & \multirow{3}{*}{$\begin{array}{l}\text { Considered as Western Mediterranean, differentiated } \\
\text { from Alboran Sea [54] }\end{array}$} \\
\hline & & Provencal Sea & \\
\hline & & Spanish waters & \\
\hline & & Alboran Sea & $\begin{array}{l}\text { Considered as independent from the Western } \\
\text { Mediterranean [54] }\end{array}$ \\
\hline \multirow[t]{5}{*}{ Short-beaked common dolphin } & \multirow[t]{2}{*}{ Atlantic Ocean } & Azores Islands & \multirow[t]{2}{*}{ Considered as a single Atlantic population [55] } \\
\hline & & Canary Islands & \\
\hline & \multirow[t]{3}{*}{ Mediterranean Sea } & Tyrrhenian Sea & \multirow{2}{*}{$\begin{array}{l}\text { Considered as Western Mediterranean, differentiated } \\
\text { from Alboran Sea [56] }\end{array}$} \\
\hline & & Sardinian waters & \\
\hline & & Alboran Sea & $\begin{array}{l}\text { Considered as independent from the Western } \\
\text { Mediterranean [56] }\end{array}$ \\
\hline \multirow[t]{8}{*}{ Striped dolphin } & \multirow[t]{2}{*}{ Atlantic Ocean } & Azores Islands & \multirow[t]{2}{*}{ Considered as a single Atlantic population $[57,58]$} \\
\hline & & Canary Islands & \\
\hline & \multirow[t]{6}{*}{ Mediterranean Sea } & Ligurian Sea & \multirow{5}{*}{$\begin{array}{l}\text { Considered as Western Mediterranean, differentiated } \\
\text { from Alboran Sea [57-59] }\end{array}$} \\
\hline & & Tyrrhenian Sea & \\
\hline & & Provencal Sea & \\
\hline & & Balearic waters & \\
\hline & & Spanish waters & \\
\hline & & Alboran Sea & $\begin{array}{l}\text { Considered as independent from the Western } \\
\text { Mediterranean }[59,60]\end{array}$ \\
\hline
\end{tabular}


the Atlantic populations, that might be related to prey resources competition [64]. Within the Mediterranean, significant population differentiation between the Eastern and the Western (Alboran Sea) specimens at both nuclear and mtDNA markers [56] evolved recently, and is likely to have been reinforced by a recent bottleneck event [64]. Furthermore, Natoli et al. [64] suggested that the adaptation to different environments or the foraging strategies adopted might be driving factors for genetic differentiation in this species.

Striped dolphins - Genetic data based both on nuclear and mtDNA analyses report no sharing of haplotypes between the two ocean basins $[57,58,65]$. However, due to the low number of nuclear loci used and that mtDNA identifies only female mediated gene flow, a male mediate gene flow could still happen. No genetic data are available for the striped dolphins of the Azores and Canary islands. However, Burret et al. [58] proposed a high level of polymorphism within the Atlantic population, suggested also by the wide-ranging pattern of the species in the pelagic Northeast Atlantic [58, 66, 67]. In the Mediterranean, evidence of an intra-basin genetic structure has been found particularly between Eastern and Western populations [68]. Furthermore, within the Western Mediterranean, populations from Spain (Alboran Sea and Balearic Islands) seem to be different from the ones in Western Italy (Ligurian and Thyrrenyan Sea), possibly as a result of the dispersal behavior due to a combination of physical and ecological characteristics.

\section{Environmental features}

The Azores Archipelago is a Mid-Atlantic island chain located in between two current systems: the Gulf Stream that generates meanders and filaments from the western side, and the Azores Current propagating eastward and generating westward eddies [69]. Furthermore, the highpressure system generates a wind stress gradient affecting transports as well as the turbulent ocean features. They generate a confluence zone, enriching the area with nutrients, and contributing to enhancing local productivity [69]. As well as the Canary Islands, both the archipelagos have a volcanic origin and are characterized by a high depth seafloor scattered by seamounts made up of summit plateaus and steep flanks. These last Islands rise off the north-west African coast. Distinct currents and countercurrents cross the Canary archipelago, making the region a complex system driven by local and remote forcing [70]. The most important is the Canary Current, fed by the easternmost branch of the Azores Current, and the Canary Upwelling Current that generates a near-permanent upwelling of relatively cool North Atlantic waters. Finally, the Eastern Boundary Current flows between the Canary Islands and the African boundary can be considered a large-scale flow with seasonal shift [70].
The Western Mediterranean can be subdivided into main regions: the Alboran Sea, the Algero-Balearic Basin, the Corso-Ligure-Provencal Basin and the Tyrrhenian Sea. The ecology and biogeography of these areas are shaped and characterized by drivers such as bottom morphology, water temperature, salinity, wind regimes, temporal thermoclines and currents, among others [71]. The Alboran Sea, between southern Spain and Morocco, is divided from the rest of the Western Mediterranean by the semipermanent Almería-Oran Front, formed by the convergence of two distinct water masses: the less saline Atlantic waters in the western area and the more saline Mediterranean waters to the east [72]. The general circulation of the basin is strongly influenced also by the complex physiography of the area made up of ridges, valleys and banks.

The Atlantic waters, coming from the Alboran sea, flows southward in the Algerian Basin, the largest of the Western Mediterranean, between the Balearic Chain and the Algerian margin. Here, an energetic mesoscale circulation pattern generates an intense inflow and outflow regime that has repercussions on biochemical parameters [73]. Therefore, locally and episodically high chlorophyll or primary production can modulate the biological activity of the ecosystems [73].

High levels of primary production are known to characterize the Corso-Ligure-Provencal Basin, where the spring phytoplankton bloom is mainly driven by the cyclonic circulation system. This system generates a frontal zone among the coastal and offshore waters and an upwelling of cold waters nutrient-rich with spatiotemporal interannual changes [74].

The Tyrrhenian Sea is located along the western coast of Italy, eastern of the islands of Corsica and Sardinia. Surface circulation of the water masses is dominated by the entrance of the Atlantic waters from southwest that splits into a vein directed north/northeast and another that proceeds farther eastward along the northern Sicilian coast [75]. The Sea is relatively deep and characterized by a large number of seamounts (64), that affect the productivity of offshore ecosystems and attract pelagic top predators [76].

Basing on the environmental and genetic features previously described, that can generate units isolated enough to be considered separately for management purposes, we tested:

1. the effect of geographic isolation by comparing whistles characteristics of dolphins inhabiting the Atlantic Ocean versus the Mediterranean Sea;

2. the effect of genetics, regardless the isolation by comparing whistles characteristics of dolphins inhabiting the Atlantic Ocean versus the Alboran Sea versus the Mediterranean Sea; 
3. the effect of habitat, regardless isolation and genetics by comparing whistles characteristics of dolphins inhabiting the different localities sampled: Azores and Canary Islands (in the Atlantic Ocean), Alboran Sea, Ligurian Sea, Tyrrhenian Sea, Sardinian waters, Provençal Sea, Spanish waters and Balearic Sea (in the Mediterranean Sea).

\section{Sampling}

Dolphin groups were sampled at four locations, selected to maximize coverage of the East Atlantic and Mediterranean basins. In the Atlantic, we sampled at the Azores (between $36^{\circ}$ and $40^{\circ}$ latitude North and $24^{\circ}$ and $32^{\circ}$ longitude West), and the Canary Islands (between $27^{\circ}$ and $30^{\circ}$ latitude North and $13^{\circ}$ and $19^{\circ}$ longitude West). In the Mediterranean, we sampled groups in the Alboran Sea (between $35^{\circ}$ and $36^{\circ}$ latitude North and $2^{\circ}$ and $6^{\circ}$ longitude West), and in the Western Mediterranean (between $35^{\circ}$ and $44^{\circ}$ latitude North and $2^{\circ}$ longitude West and $16^{\circ}$ East, subdivided in the six local areas previously cited (Fig. 1).

Data were collected during vessel surveys carried out in daylight hours from 1996 to 2012. We opted for a 16year timescale to include a wide temporal variation and to obtain more samples from distinct groups. To avoid any temporal mismatch, we reviewed published genetic and ecological information including data collected between 1990 and 2012. Species identification was visually confirmed for all acoustic recordings. Recordings collected in the presence of mixed-species groups were discarded, and we used only data collected when no groups of whistling species (other than the study-species) were present within one kilometer. The sampling effort for the three species is summarized in Table 2.

\section{Data collection}

Data were collected using a variety of equipment: a mono or stereo towed Benthos hydrophone AQ4 (Teledyne Benthos North Falmouth, MA; with a flat response of $62 \mathrm{~dB}$ from $200 \mathrm{~Hz}$ to $30 \mathrm{kHz}$, a $29 \mathrm{~dB}$ preamplifier and $200 \mathrm{~Hz}$ high-pass filter), an HTI-94-SSQ hydrophone (High Tech Inc., Long Beach, MS; with a linear flat response of $61 \mathrm{~dB}$ between $1 \mathrm{~Hz}$ and $15 \mathrm{kHz}$, and of $63 \mathrm{~dB}$ between 15 and $30 \mathrm{kHz}$ ), an array of two Benthos AQ4, or an array of two Benthos AQ4 and two spherical ceramic hydrophone elements (Seiche Measurements Limited Bradworthy, Holsworthy, Devon, UK; with a frequency response of $2-150 \mathrm{kHz}$ ). Sounds were collected either on a digital tape recorder TascamVR DA-P1 (TEAC America, Inc., Montebello, CA) (with a sampling frequency of $48 \mathrm{kHz}, 16$ bit resolution, and frequency responses of $60.5 \mathrm{~dB}$ from $20 \mathrm{~Hz}$ to 20 $\mathrm{kHz}$ ), or directly digitalized on a laptop at a sampling rate of $32 \mathrm{kHz}, 44.1 \mathrm{kHz}, 48 \mathrm{kHz}$ or $192 \mathrm{kHz}$. Because of the differences in sampling rates, all signals collected at a sampling rate above $48 \mathrm{kHz}$ were down-sampled to that value, because the maximum fundamental frequency of most whistles was found to be below $24 \mathrm{kHz}$.

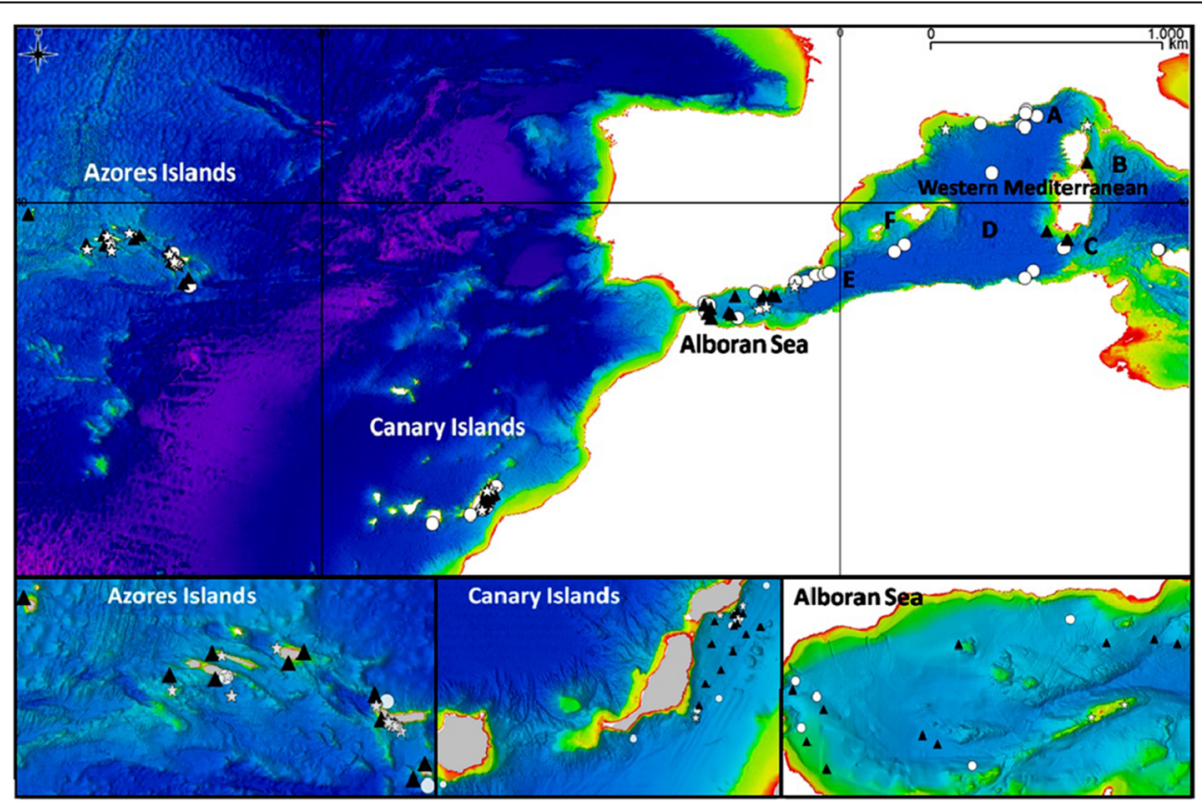

Fig. 1 Map of the ocean basins included in the study. Two sub-areas were investigated per basin. In the Atlantic Ocean: the Azores islands and the Canary Islands. In the Mediterranean Sea: the Alboran Sea, and the Western Mediterranean (A Ligurian Sea, B Tyrrhenian Sea, C Sardinian waters, D Provençal Sea, E Spanish waters, F Balearic waters). Dots represent striped dolphin sightings, stars bottlenose dolphin sightings and triangles common dolphin sightings. Map was generated by using QGis 2.2.0 (http://qgis.org/it/site) 
Table 2 Summary of the study effort for each species and each basin. For the Mediterranean, we analyzed $22.47 \mathrm{~h}$ of recordings from 38 sightings and we extracted 1293 whistles, 58.54\% of which met good quality criteria and were analyzed. For the Atlantic Ocean, we collected $17.25 \mathrm{~h}$ of recordings during 63 sightings and $45.70 \%$ of 3177 signals were analyzed

\begin{tabular}{|c|c|c|c|c|c|c|c|c|}
\hline & \multicolumn{4}{|c|}{ Mediterranean Sea } & \multicolumn{4}{|c|}{ Atlantic Ocean } \\
\hline & Hours & Sightings & $\begin{array}{l}\text { Extracted } \\
\text { Whistles }\end{array}$ & $\begin{array}{l}\text { Analyzed } \\
\text { whistles }\end{array}$ & Hours & Sightings & $\begin{array}{l}\text { Extracted } \\
\text { whistles }\end{array}$ & $\begin{array}{l}\text { Analyzed } \\
\text { whistles }\end{array}$ \\
\hline Bottlenose dolphin & 3.06 & 5 & 257 & 136 & 7.95 & 23 & 1052 & 420 \\
\hline Short-beaked common dolphin & 8.30 & 14 & 249 & 120 & 5.60 & 27 & 984 & 480 \\
\hline Striped dolphin & 11.11 & 19 & 787 & 501 & 3.70 & 13 & 1141 & 552 \\
\hline
\end{tabular}

In recordings collected with higher sampling rates, sounds $(0.81 \%)$ that went beyond the Nyquist frequency (i.e. the highest frequency that can be coded at a given sampling rate to fully reconstruct the signal, $24 \mathrm{kHz}$ in this case) were not included in the analyses. Signals sampled at $32 \mathrm{kHz}$ or $44.1 \mathrm{kHz}$ did not contain contour sections above their Nyquist frequency.

\section{Acoustic data measurements}

We used only whistles with sound pressure level (SPL) at least $20 \mathrm{~dB}$ higher than the background noise (see [42]). Nine parameters from the contour of the whistle were measured from spectrograms in CoolEdit 2.1 (Syntrillium Software, U.S.A.): signal duration, beginning, end, maximum and minimum frequency, number of inflection points (where the curvature changes sign (second derivative $=0)$ ), steps (a discontinuous change in frequency), maxima and minima of the contour (where the slope changes sign (first derivative $=0)$ ). These terms are described in Papale et al. [42]. After manual measurement (visual observation of the spectrogram), we checked our results by extracting the same parameters with a semi-automatic MatLab-based program (TRIA, Lammers M.O.) on a subsample of the data to prevent analyser-induced bias. There were not significant differences for any parameters except for maximum frequency (Sign test: $N=855,-1.09<\mathrm{Z}<-1.50,0.13<P<0.27$; for maximum freq: $\mathrm{Z}=-8.11, P<0.001)$. This discrepancy in the maximum frequency (mean value with the manual method $=16,678 \mathrm{~Hz}, \quad \mathrm{Sd}=3623.63 \mathrm{~Hz}$; mean value with the semi-automatic method $=16,411 \mathrm{~Hz}, \mathrm{Sd}=$ $3342.38 \mathrm{~Hz}$ ) is due to the low TRIA sensitivity in detecting and measuring low intensity sounds occurring at the highest frequencies. From this comparison, it emerges that human analysts can measure low intensity signals better than the automated program. To avoid pseudoreplication due to the presence of stereotyped whistles that could result from the influence of behaviour and/or social interactions, and address the independence of each whistle, sounds with similar time-frequency contours, visually matched by expert observers, were included in the analysis only once.

\section{Data analyses}

To test the effect of geographic isolation, we performed stepwise discriminant function analyses (DFA) with cross-validation. To meet normality and homoscedasticity criteria and to reduce the weight of each whistle within a recording, we used the mean (normally distributed) values of whistle parameters recorded during each sighting (acoustic encounters) for the DFA. By using as sampling unit the acoustic encounter, and as a variable the mean of each parameter for each encounter, we also met the independence criterion. Even if social structure varies considerably among populations, dolphins living in fission-fusion societies associate in small groups that change in composition on a daily or hourly basis [77]. When in the same location, data were collected during surveys in different years and recorded at an average minimum distance of at least $10 \mathrm{~km}$. If the distance was smaller than a couple of kilometers, the temporal gap between the two sightings was at least $24 \mathrm{~h}$ in order to prevent recording the same group of dolphins. As a consequence, the number of acoustic encounters per species ranged from 5 to 19 for the Mediterranean and 13-24 for the Atlantic Ocean. Given that small sample sizes can reduce power and affect statistical inference reliability, we considered the results reliable if the resulting discriminant model was based on only few variables, following the principle that a higher number of variables compared to the number of cases can lead to a poor discriminant rate.

To test the effect of genetics, regardless the isolation and the effect of habitat, regardless isolation and genetics, we considered the single signals as units in order to maintain all the intra-sighting variability. Due to the visual acoustic preliminary analysis previously described, potential issues of pseudo-replication were avoided. Furthermore, only sightings with at least three good quality whistles were included [see 43 for details].

In order to deal with a dataset that violates the a priori assumption of normality and homoscedasticity, we used the Random Forest (RF) machine learning method [78]. This methodological approach has been successfully implemented on structurally similar data in recent 
ecological studies [79-82], in which the high heterogeneity of the ecological data encourages the use of approaches not based on a priori assumptions regarding the distribution of input data.

We implemented six RF models with three species (bottlenose dolphin, short-beaked common dolphin, striped dolphin) and two response variables (genetic units, geographical groups).

We used whistle frequency (maximum, minimum, beginning and final frequency $[\mathrm{Hz}]$ ) and duration $[\mathrm{s}] \mathrm{pa}-$ rameters in the RF models because these variables had lower Coefficients of Variation (CV) than those that describe modulation patterns (number of inflection points, of steps, of minima and of maxima). We constructed classification trees using a bootstrap aggregating algorithm [83] that allowed a reduced variance of predicted values and decreased risk of overfitting. Consequently, each tree was built on a randomly sub-sampled training dataset, while the subsequent predictions were carried out considering the remaining data (called Out-Of-Bag, $\mathrm{OOB}$ ) allowing an unbiased estimate of the classification error. Predictor variables were selected from a random subsample of variables at each split [78]. Optimal model parameters (i.e. number of trees and number of random variables considered at each split) were identified by setting up a grid of tuning parameters to maximize correct predictions, using the OOB (Out-Of-Bag) estimate of misclassification rates as a measure of model performance. Consequently, 2500 trees and 2 random variables at each split emerged as a good compromise between optimized performance and computation time and thus were considered in the models. Variable importance was used as a measure of the contribution of each predictor variable to the fitted model. Variable importance was calculated based on the mean decrease in accuracy (MDA) for each variable, where MDA is the normalized difference of the classification accuracy between two models, one considering the original predictor and one considering a randomly permuted predictor [84]. In RF, as in all machine learning models, the class imbalance leads to inaccurate results, especially for the minority classes that could be not well predicted as poorly represented during the learning process. As the number of the sightings and the number of the whistles were not unequal among groups (Supplementary 1), we used the Synthetic Minority Over-sampling Technique (SMOTE) [85] to balance the number of observations among classes before performing RF analysis. This method carry out both an oversampling of the minority classes and an undersampling of the majority classes and is particularly appropriate as pre-processing method with the aim at equalizing the number of observation among groups before implementing machine learning techniques [86].
Random Forest models and SMOTE technique has been implemented using respectively the "randomForest" [84] and "UBL" [87] packages in $\mathrm{R}$ environment (v. 3.6.2), while the statistical software package PASW STATISTICS 18.0 (SPSS Institute Inc., Chicago, IL) was used for descriptive statistics of variation (mean, standard deviation, coefficients of variation).

\section{Results}

We collected $39.72 \mathrm{~h}$ of recordings during 104 acoustic encounters and analyzed 2209 whistles. For the Mediterranean, we analyzed $22.47 \mathrm{~h}$ of recordings from 38 sightings and we extracted 1293 whistles (855 in the Western Mediterranean and 438 in the Alboran Sea, 58.54\% of which met good quality criteria and were analyzed. For the Atlantic Ocean, we collected $17.25 \mathrm{~h}$ of recordings during 63 sightings and $45.70 \%$ of 3177 (1516 whistles collected in the Azores and 1661 collected in the Canary Islands) signals were analyzed. Data collection is summarized in Table 2.

All whistle parameters exhibited intra-specific variation higher than $10 \%$. By contrasting variability of frequency parameters with those of duration and modulation (number of inflection points, of steps, of minima and of maxima), we found that CVs of signal duration were intermediate (ranging from 27.19 to $66.97 \%$ ) between those of frequency (ranging from 10.19 to $46.21 \%$ ) and modulation parameters (ranging from 65.12 to $230.44 \%$ ).

\section{The effect of geographic isolation}

The values of parameters obtained from Mediterranean and Atlantic whistles allowed us to correctly assign, through DFA, more than $83 \%$ of whistles to their basin of origin: $93.8 \%$ for striped dolphin, $85.7 \%$ for bottlenose dolphin and $83.8 \%$ for short-beaked common dolphin (respectively: Fisher's F $=21.10$, Wilks' Lambda $=0.41$, $P<0.001$, coefficients of the function: number of inflection points $=-1.40$, number of minima $=1.46$; Fisher's $\mathrm{F}=28.02$, Wilks' Lambda $=0.54, P<0.001$, coefficients of the function: end frequency $=0.90$, number of inflection points $=0.82$ Fisher's $\mathrm{F}=10.73$, Wilks' Lambda $=0.38, P<$ 0.001 , coefficients of the function: number of inflection points $=1.42$, number of maxima $=-0.94)($ Table 3$)$. The number of inflection points contributed to the distinction for all three species, while the number of maxima contributed only for common dolphin, the number of minima for striped dolphin, and the end frequency only for bottlenose dolphin. Correct assignment of the smallest sample was within the range of all the assignments obtained in the DFA (Mediterranean bottlenose dolphin 80\%).

\section{The effect of genetics, regardless the isolation}

Given the strong match between genetic and acoustic divergence recorded for the individuals living in the Atlantic Ocean and in the Mediterranean Sea, we 
Table 3 Detailed results of the DFAs (all significant $P<0.001$ ) obtained from Mediterranean and Atlantic recordings. All whistles parameters were used to built the model. The range of the correct assignment is $66.7-100 \%$ for the Mediterranean Sea and $84.6-$ 92.0\% for the Atlantic Ocean

\begin{tabular}{|c|c|c|c|c|}
\hline \multirow{2}{*}{ Bottlenose dolphin } & & & \multicolumn{2}{|c|}{ Predicted group membership (\%) } \\
\hline & & & Mediterranean Sea & Atlantic Ocean \\
\hline & Original & Mediterranean Sea $(n=5)$ & 80.0 & 20.0 \\
\hline & & Atlantic Ocean $(n=23)$ & 13.0 & 87.0 \\
\hline & Cross-validated & Mediterranean Sea & 80.0 & 20.0 \\
\hline & & Atlantic Ocean & 13.0 & 87.0 \\
\hline \multicolumn{5}{|c|}{$\begin{array}{l}\text { Short-beaked common } \\
\text { dolphin }\end{array}$} \\
\hline & Mediterranean Sea & Atlantic Ocean & & \\
\hline & Original & Mediterranean Sea $(n=14)$ & 66.7 & 33.3 \\
\hline & & Atlantic Ocean $(n=27)$ & 8.0 & 92.0 \\
\hline & Cross-validated & Mediterranean Sea & 66.7 & 33.3 \\
\hline & & Atlantic Ocean & 8.0 & 92.0 \\
\hline \multirow[t]{5}{*}{ Striped dolphin } & & & Mediterranean Sea & Atlantic Ocean \\
\hline & Original & Mediterranean Sea $(n=19)$ & 100.0 & 0.0 \\
\hline & & Atlantic Ocean $(n=13)$ & 7.7 & 92.3 \\
\hline & Cross-validated & Mediterranean Sea & 100.0 & 0.0 \\
\hline & & Atlantic Ocean & 15.4 & 84.6 \\
\hline
\end{tabular}

examined whether a similar pattern could be found when considering the groups of the western Mediterranean Sea, the Alboran Sea and the Atlantic Ocean. Random forest analysis resulted in low estimated values of classification error $(\mathrm{OOB}$ estimate of error rate: bottlenose dolphin $=$ $16.61 \%$; short-beaked common dolphin $=22.69 \%$; striped dolphin $=25.97 \%$ ), showing a high level of discrimination among the genetic groups considered. Variable importance analysis allowed us to identify the variables that contributed the most to classification accuracy (Fig. 2). End and minimum frequencies exerted the most influence in discriminating bottlenose dolphins among the three areas, while maximum frequency, duration of the signals and beginning frequency were the most relevant parameters for distinguishing short beaked common and striped dolphins among the three areas (Fig. 2).

The effect of habitat, regardless isolation and genetics Given that many factors act on acoustic parameters, we verified to what extent the general scenario was

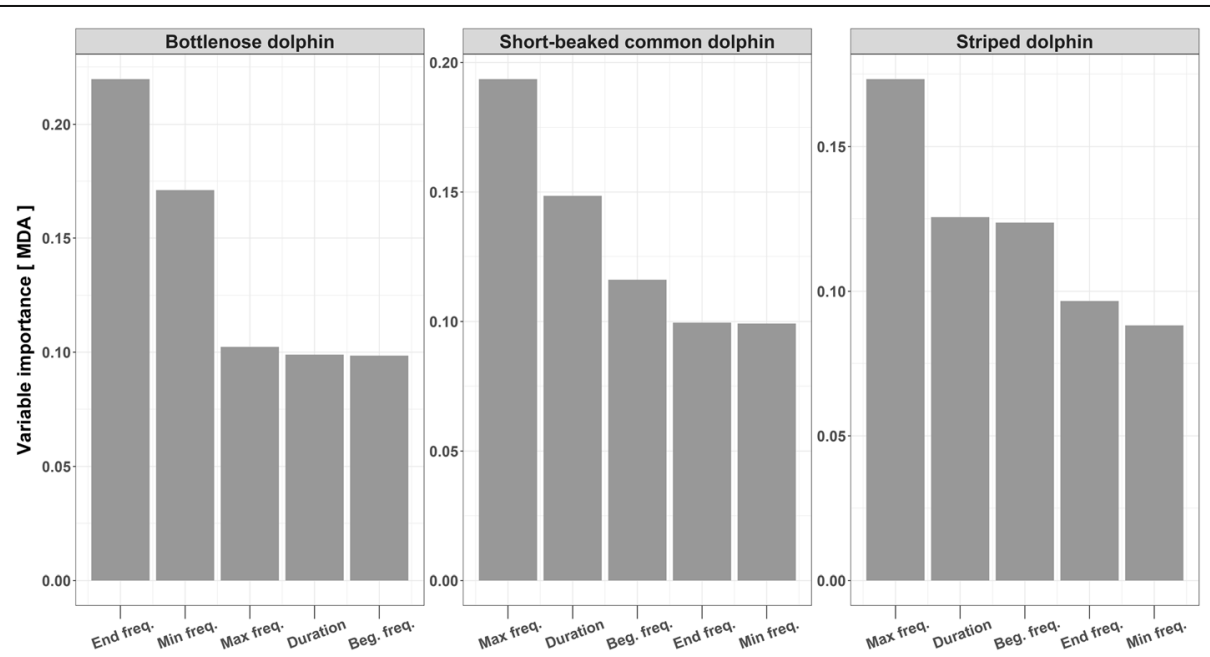

Fig. 2 Variable importance for the correct classifications of the groups as estimated by the Random Forest Analysis performed in order to determine the effect of genetics on whistle structure regardless isolation (i.e. using samples from the Mediterranean Sea, the Alboran Sea and the Atlantic Ocean) 
distinguishable, both within the Mediterranean and the Atlantic. Tests performed in relation to local areas showed that, for all the species, the OOB estimate of the classification error was in any case lower than $38 \%$, in spite of the higher number of groups considered, which ranged between five (short-beaked common dolphin) and eight (striped dolphin) (Supplementary 1). Within the Atlantic, end and minimum frequency continued to have the highest importance for correct classification of bottlenose dolphin observations. In the other two species, maximum frequency remained the most influential parameter. Within the Mediterranean Sea, high discrimination was highlighted for all the species. For bottlenose dolphins, minimum frequency remained important for distinguishing among groups; duration remained the most important parameter for distinguishing short-beaked common dolphins groups, while maximum frequency remained the most important parameter for striped dolphins. In all three cases, the beginning frequency was also an important parameter in the classification models.

\section{Discussion}

Our results suggest that the features of delphinids' whistles may be useful to outline the presence of distinct groups basing on genetic and environmental features. Examining the effect of geographic isolation, the effect of genetics, regardless the isolation and the effect of habitat, regardless isolation and genetics on the vocalizations of the three different species studied, we provide a new framework for characterize differentiation and inform management decisions.

Distinct UCs, isolated by the geographic barrier created by the Strait of Gibraltar (Atlantic vs. Mediterranean) can be identified acoustically at a correct classification score to greater than $83 \%$. Differences in the spectral and temporal features of whistles matched the geographic isolation suggesting that it may translate into differences in acoustic parameters. Samarra et al. [88] found a similar result by analyzing killer whale's whistles recorded in the Atlantic and in the Pacific Ocean. Indeed, isolated killer whales' populations showed a stronger divergence in frequency parameters compared to the variation detected at an intra-basin level (i.e. Iceland and Norway). However, genetically distinct killer whales, not completely geographically isolated, exhibited a level of variation still useful for distinguishing populations. In agreement with this study, the variability of dolphin whistles observed are consistent with genetic differences, also regardless geographic isolation and reflects population structure. As suggested by Samarra et al. [88], acoustic differences may reflect both historical geographic isolation and a more recent divergence between adjacent populations.
The discriminant power of acoustic signals is prominent between ocean basins, where the gene flow is presumably lower than it is within ocean basins. However, acoustic analysis reveals to be once again a good tool to potentially delineate the range of different genetic groups even over geographically close areas.

A relation among genetic features and acoustic pattern has been already demonstrated also for North Atlantic fin whales [89] and sperm whales [90]. In these cases, acoustic variability has been linked to segregation possibly generated by dispersal range and/or social characteristics. The causes of variation can be different among species, since the variability might partially derive from other factors which can generate local changes in the acoustic characteristics of signals, independently of genetic or ecological differences, such as group size, group composition, behavioural state and vocal learning [44, 91]. Animal culture and social structure indeed have the potential to affect acoustic processes in several ways [92]. As said before, delphinid species are capable of both vertical (from parents to offspring) and horizontal (among peers) cultural transmission [37]. Their social structure and cultural changes could play a crucial role in driving isolation among pods, and promoting different reactions to local conditions, highlighting the role of gene-culture coevolution in acoustic processes. In this work, we did not consider these parameters that, due to the sampling design, could be over-represented or not represented, and therefore could possibly have an influence on the results.

However, our results show also that whistles can be predictive of the finer-scale habitat-driven population structure, both in the Atlantic and in the Mediterranean, where dolphin populations are known to be structured based on local habitat dependencies [54, 56, 59, 61, 68]. Habitat features (both environmental and anthropogenic) are considered drivers of whistle changes [24, 44, 93] and their variation could represent an adaptation to signal transmission in the environment or caused by genetic differences related to the habitat niche differentiation. Recently, genetic differentiations have been detected in the form of offshore and coastal ecotypes, in particular for Tursiops truncatus both in the Atlantic and in the Mediterranean [63]. However, since information is still scarce in some areas for the species considered, and our samples were obtained both in coastal and in offshore waters, different ecotypes could have been sampled. Therefore, even though the Random Forest classification model highlighted that the whistles were highly classified to the assigned group, the current variability should be better investigated. Indeed, our limited sample size may not capture all of the variability in the whistle repertoires of these populations and may not provide a complete picture of the similarities and 
differences between populations. Considering a higher number of recordings and increasing the sampling area could reveal possible connections or stronger differences among groups.

\section{Conclusions}

The preliminary map of acoustic patterns drawn from this study suggests that comparison of the acoustic characteristics of whistles can be a tool to complement genetic methods usually applied to identify distinct UCs for at least some delphinid species.

We recommend that acoustic analysis be embedded in assessments of delphinid population structure, together with genetics and ecological tracer analysis. Passive acoustic monitoring systems represent a cost-efficient non-invasive method to collect signals for identifying potential units of conservation, based on its correlation with other lines of evidence (e.g. genetic data). Acoustics studies provide a framework to guide population viability analyses that can be applied over larger spatial and temporal scale, improving efforts in the management of units in need of conservation.

\section{Abbreviations}

UC: Unit of Conservation; ESU: Evolutionarily Significant Unit; MU: Management Unit; mtDNA: mitochondrial DNA; SPL: Sound Pressure Level; DFA: Discriminant Function Analysis; RF: Random Forest; OOB: Out-ofBag; MDA: mean decrease in accuracy; SMOTE: Synthetic Minority Oversampling Technique

\section{Supplementary Information}

The online version contains supplementary material available at https://doi. org/10.1186/s40850-021-00085-7.

Additional file 1. Supplementary 1 Results of the Random Forest Analysis. Mediterranean and Atlantic sites are indicated by the letters $M$ and $A$ respectively. Acoustic parameters are reported in order of variable importance as estimated by the model and the most important variables (i.e. Mean Decrease Accuracy > 0.2) are indicated in bold. Names of acoustic parameters are abbreviated as follows: dur=duration; beg.f $=$ beginnig frequency; end.f = end frequency; min.f = minimum frequency; max.f $=$ maximum frequency.

\section{Acknowledgements}

The authors are grateful to IFAW and ALNITAK for their contribution in the data collection. Without their support, this project could not have been accomplished. Also, we would like to thank Emilio Balletto, Dan Chamberlain and Michael Ryan for their useful suggestions.

\section{Authors' contributions}

EP participated in the design of the study, collected and analyzed recordings, performed the statistical analysis and wrote the manuscript with inputs from all other authors. MA participated in designing the study for the Mediterranean basin, contributed to data collection, analyzed Mediterranean recordings and contributed to the preparation of the manuscript. IC, AG, VM JNO, MP, RP, MAS contributed to data collection and the preparation of the manuscript. MT contributed to statistical analysis and the preparation of the manuscript. MOL contributed to coordinating the study, as well as to its technical design and to the preparation of the manuscript. CG initiated, financed and coordinated the study, contributed to its technical design and to the preparation of the manuscript. All authors read and approved the final manuscript.

\section{Funding}

Data collection and processing in the Azores was funded by Fundação para a Ciência e a Tecnologia (FCT) and Fundo Regional da Ciência e Tecnologia (FRCT), through research projects TRACE-PTDC/MAR/74071/2006 and MAPC ET-M2.1.2/F/012/2011 (FEDER, the Competitiveness Factors Operational (COMPETE), QREN European Social Fund, and Pro convergencia Açores/EU Program). We also thank FCT for supporting MARE (UID/MAR/04292/2019) and OKEANOS (UIB/05634/2020), as well as for the research grants awarded to PR (SFRH/BPD/108007/2015) and CI (Project Awareness - PTDC/BIA-BMA/ 30514/2017). SMA is supported through project SUMMER (H2020-EU.3.2.3.1, GA 817806). Data collection by SECAC was funded by the EU LIFE programme-project LIFE INDEMARES (LIFE 07/NAT/E/000732) — and the Fundación Biodiversidad under the Spanish Ministry of Environment, Rural and Marine Affairs (project ZEC-TURSIOPS). EP was supported by a LLP/Erasmus grant 2010-2011 for collecting data in the Canary Islands.

\section{Availability of data and materials}

The datasets generated during the current study are available from the corresponding author on reasonable request.

\section{Declarations}

Ethics approval and consent to participate

No ethics approval was required.

Consent for publication

Not applicable.

\section{Competing interests}

The authors declare no competing financial interests.

\section{Author details}

${ }^{1}$ Institute for the Study of Anthropic Impacts and Sustainability in the Marine Environment (CNR-IAS), unit of Capo Granitola, National Research Council, Via del Mare 3, 91021 Campobello di Mazara, TP, Italy. ${ }^{2}$ Life Sciences and Systems Biology Department, University of Torino, Via Accademia Albertina 13, 10123 Torino, Italy. ${ }^{3}$ IMAR - Institute of Marine Research \& OKEANOS R\&D Centre; University of the Azores, Horta, Portugal. ${ }^{4}$ Groupe de Recherche sur les Cétacés, Antibes, France. ${ }^{5}$ Hawaii Institute of Marine Biology, University of Hawaii, Kaneohe, HI 96744, USA. ${ }^{6}$ Ocean wide Science Institute, PO Box 61692, Honolulu, HI 96744, USA. 7 Society for the Study of Cetaceans in the Canary Archipelago (SECAC). Casa de Los Arroyo, Avda. Coll n6, Apartado de Correos 49 de Arrecife de Lanzarote, 35500 Arrecife, Lanzarote, Spain. ${ }^{8}$ Sea Mammal Research Unit, Scottish Oceans Institute, University of St Andrews, St Andrews, Scotland. ${ }^{9}$ MARE - Marine and Environmental Sciences Centre, Lisbon, Portugal. ${ }^{10}$ Biology Department, Woods Hole Oceanographic Institution, Woods Hole, MA 02543, USA.

Received: 30 December 2020 Accepted: 31 May 2021

Published online: 29 July 2021

\section{References}

1. Casacci LP, Barbero F, Balletto E. The "Evolutionarily Significant Unit" concept and its applicability in biological conservation. Ital J Zool. 2014; 81(2):182-93. https://doi.org/10.1080/11250003.2013.870240.

2. Giménez J, Louis M, Barón E, Ramírez F, Verborgh P, Gauffier P, et al. Towards the identification of ecological management units: $A$ multidisciplinary approach for the effective management of bottlenose dolphins in the southern Iberian Peninsula Aquatic Conserv. Mar Freshw Ecosyst. 2018;28:205-15.

3. Fraser DJ, Bernatchez L. Adaptive evolutionary conservation: towards a unified concept for defining conservation units. Mol Ecol. 2001;10(12): 2741-52.

4. Funk WC, McKay JK, Hohenlohe PA, Allendorf FW. Harnessing genomics for delineating conservation units. Trends Ecol Evol. 2012;27(9):489-96. https:// doi.org/10.1016/j.tree.2012.05.012

5. Ryder OA. Species conservation and systematics: the dilemma of subspecies. Trends in Ecology and Evolution. 1986;1(1):9-10. https://doi. org/10.1016/0169-5347(86)90059-5. 
6. Crandall KA, Bininda-Emonds ORP, Mace GM, Wayne RK. Considering evolutionary processes in conservation biology. Trends Ecol Evol. 2000;17: $390 Ð 395$.

7. de Guia APO, Saitoh T. The gap between the concept and definitions in the evolutionarily significant unit: the need to integrate neutral genetic variation and adaptive variation. Ecol Res. 2007;22(4):604-12. https://doi. org/10.1007/s11284-006-0059-z

8. Wilkins MR, Seddon N, Safran RJ. Evolutionary divergence in acoustic signals: causes and consequences. TREE. 2013;28(3):156-66. https://doi.org/10.1016/j. tree.2012.10.002

9. Van Schaik CP. The costs and benefits of flexibility as an expression of behavioural plasticity: a primate perspective. Phil Trans R Soc B. 2013; 368(1618):20120339. https://doi.org/10.1098/rstb.2012.0339.

10. Kamilar JM, Cooper N. Phylogenetic signal in primate behaviour, ecology, and life history. Phil Trans R Soc B. 2013;368:20120341.

11. Kessler SE, Radespiel U, Hasiniaina AIF, Leliveld LMC, Nash LT, Zimmermann E. Modeling the origins of mammalian sociality: moderate evidence for matrilineal signatures in mouse lemur vocalizations. Front Zool. 2014;11(1): 14. https://doi.org/10.1186/1742-9994-11-14.

12. Gerhardt $\mathrm{CH}$. Female mate choice in treefrogs: static and dynamic acoustic criteria. Anim Behav. 1991:42:615-35.

13. Ryan MJ, Cocroft RB, Wilczynski W. The role of environmental selection in intraspecific divergence in mate recognition signals in the cricket frog. Acris crepitans Evol. 1990;44(7):1869-72. https://doi.org/10.1111/j.1558-5646.1990. tb05256.x.

14. Castellano S, Tontini L, Giacoma C, Lattes A, Balletto E. The evolution of release and advertisement calls in green toads (Bufoviridis complex). Biol J Linn Soc. 2002;77(3):379-91. https:/doi.org/10.1046/j.1095-8312.2002.00118.x.

15. Sanvito S, Galimberti F, Miller ED. Development of aggressive vocalizations in male southern elephant seals (Mirounga leonina): maturation or learning? Behaviour. 2008;145:137-70.

16. Romer $\mathrm{H}$. Environmental and biological constraints for the evolution of long-range signalling and hearing in acoustic insects. Phil Trans R Soc Lond B. 1993;340:179-85.

17. Giacoma C, Castellano S. Advertisement call variation and speciation in the Bufoviridis complex. In: Ryan MJ, editor. Anuran communication. Washington and London: Smithsonian Institution Press; 2001. p. 205-19.

18. Gish SL, Morton ES. Structural adaptations to local habitat acoustics in Carolina wren songs. Z Tierpsychol. 1981;56:74-84.

19. Brumm H, Naguib M. Environmental acoustics and the evolution of bird song. Adv Study Behav. 2009;40:1-33.

20. Brown $\mathrm{CH}$, Waser PM. Environmental influences on the structure of primate vocalizations. In: Todt D, Goedeking P, Symmes D, editors. Primate Vocal Communication. Berlin: Springer-Verlag; 1988. p. 51-66. https://doi.org/10.1 007/978-3-642-73769-5_4.

21. Brown $\mathrm{CH}$, Gomez R, Waser PM. Old world monkey vocalizations: adaptation to the local habitat? Anim Behav. 1995;50:945-61.

22. Maretti G, Sorrentino V, Finomana A, Gamba M, Giacoma C. Not just a pretty song: an overview of the vocal repertoire of Indri indri. J Anthropol Sci. 2010;88:151-65.

23. Au WWL, Floyd WR, Haun JE. Propagation of Atlantic bottlenose dolphin echolocation signals. J Acoustic Soc Am. 1978;64(2):411-22. https://doi.org/1 $0.1121 / 1.382015$

24. Papale E, Gamba M, Perez-Gil M, Martin VM, Giacoma C. Dolphins adjust species-specific frequency parameters to compensate for increasing background noise. PLoS ONE. 2015;10(4):e0121711. https://doi.org/10.1371/ journal.pone.0121711.

25. Whitehead H. Gene-culture coevolution in whales and dolphins 2017PNAS $114:$ 7814-7821.

26. May-Collado LJ, Agnarsson I, Wartzok D. Reexamining the relationship between body size and tonal signals frequency in whales: a phylogenetic comparative approach. Mar Mam Sci. 2007;23(3):524-52. https://doi.org/1 0.1111/j.1748-7692.2007.02250.x.

27. Thinh VN, Hallam C, Roos C, Hammerschmidt K. Concordance between vocal and genetic diversityin crested gibbons. BMC Evol Biol. 2011;11:1-9.

28. Ruppell J. Vocal diversity and taxonomy of white-cheeked crested gibbons. J Acoust Soc Am. 2014;135(4):2239. https://doi.org/10.1121/1.4877326.

29. Campbell P, Pasch B, Pino JL, Crino OL, Phillips M, Phelps SM. Geographic variation in the songs of Neotropical singing mice: testing the relative importance of drift and local adaptation. Evolution. 2010;64(7):1955-72. https://doi.org/10.1111/j.1558-5646.2010.00962.x.
30. Pasch B, Campbell P, Abbasi MZ, Wilson PS, Phelps SM, Ryan MJ. Sources of acoustic variation in the advertisement vocalizations of Neotropical singing mice. J Acoust Soc Am. 2014;135(4):2239. https://doi.org/10.1121/1.4877325.

31. Tobias JA, Seddon N, Spottiswoode CN, Pilgrim JD, Fishpool LD, Collar NJ. Quantitative criteria for species delimitation. Ibis. 2010;152(4):724-46. https:// doi.org/10.1111/J.1474-919x.2010.01051.X.

32. Marler P. A comparative approach to vocal learning: song development in white-crowned sparrows. J Comp Physiol Psychol Monograph. 1970;71:1-25.

33. Kluender KR, Diehl RL, Killeen PR. Japanese quail can learn phonetic categories. Science. 1987;237(4819):1195-7. https://doi.org/10.1126/science.3 629235.

34. Beecher MD, Campbell SE, Stoddard PK. Correlation of song learning and territory establishment strategies in the song sparrow. ProcNatlAcad Sci USA. 1994;91(4):1450-4. https://doi.org/10.1073/pnas.91.4.1450.

35. Salinas-Melgoza A, Wright TF. Evidence for vocal learning and limited dispersal as dual mechanisms for dialect maintenance in a parrot. PLoS One. 2012;7(11):e48667. https://doi.org/10.1371/journal.pone.0048667.

36. Tyack PL, Sayigh LS. Vocal learning in cetaceans. In: Snowdon CT, Hausberger M, editors. Social influences on vocal development. Cambridge University Press: Cambridge; 1997. p. 208-33. https://doi.org/10.1017/ CBO9780511758843.011.

37. Janik VM, Slater PJB. The different roles of social learning in vocal communication. Anim Behav. 2000;60:1-11.

38. Janik VM. Acoustic communication in delphinids. Adv Study Behav. 2009;40: 123-57. https://doi.org/10.1016/S0065-3454(09)40004-4.

39. Hawkins ER. Geographic variations in the whistles of bottlenose dolphins (Tursiops aduncus) along the east and west coasts of Australia. J Acoust Soc Am. 2010;128(2):924-35. https://doi.org/10.1121/1.3459837.

40. Azzolin M, Papale E, Lammers MO, Gannier A, Giacoma C. Geographic variation of whistles of striped dolphin (Stenellacoeruleoalba) within the Mediterranean Sea. J Acoust Soc Am. 2013;134:694-705.

41. Papale E, Azzolin M, Cascão I, Gannier A, Lammers MO, Martin VM, Oswald J, Perez-Gil M, Prieto R, Silva MA, Giacoma C. Acoustic divergence between bottlenose dolphin whistles from the Central-Eastern North Atlantic and Mediterranean Sea. Acta Ethol. 2013a;DOI https://doi.org/10.1007/s10211013-0172-2.

42. Papale E, Azzolin M, Cascão I, Gannier A, Lammers MO, Martin VM, et al. Geographic variability in the acoustic parameters of striped dolphin's (Stenella coeruleoalba) whistles. J Acoust Soc Am. 2013b;133(2):1126-34.

43. Papale E, Azzolin M, Cascão I, Gannier A, Lammers MO, Martin VM, et al. Macro and micro geographic variation of short-beaked common dolphin's (Delphinus delphis) whistles in the Mediterranean Sea and Atlantic Ocean. Ethol Ecol Evol. 2013c;26(4):392-404. https://doi.org/10.1080/03949370.2013. 851122.

44. La Manna G, Rako-Gospić N, Sarà G, Gatti F, Bonizzoni S, Ceccherelli G. Whistle variation in Mediterranean common bottlenose dolphin: the role of geographical, anthropogenic, social, and behavioral factors. Ecology and Evolution. 2020;10(4):1971-87. https://doi.org/10.1002/ece3.6029.

45. Papale E, Perez-Gil M, Castrillon J, Perez-Gil E, Ruiz L, Servidio A, et al. Context specificity of Atlantic spotted dolphin acoustic signals in the Canary Islands. Ethology Ecology \& Evolution. 2017;29(4):311-29. https://doi.org/10.1 080/03949370.2016.1171256.

46. Fripp D, Owen C, Quintana-Rizzo E, Shapiro A, Buckstaff K, Jankowski K, et al. Bottlenose dolphin (Tursiops truncatus) calves appear to model their signature whistles on the signature whistles of community members. Anim Cogn. 2005;8(1):17-26. https://doi.org/10.1007/s10071-004-0225-z.

47. Terry AMR, Peake TM, McGregor PK. The role of vocal individuality in conservation. Front Zool. 2005;2(1):10. https://doi.org/10.1186/17429994-2-10.

48. Matthews JN, Rendell LE, Gordon JCD, MacDonald DW. A review of frequency and time parameters of cetacean tonal calls. Bioacoustics. 1999; 10(1):47-71. https://doi.org/10.1080/09524622.1999.9753418.

49. Van Cise AM, Roch MA, Baird RW, Mooney AT, Barlow J. Acoustic differentiation of Shiho- and Naisa-type short-finned pilot whales in the Pacific Ocean. J Acoust Soc Am. 2017;141:737-48. https://doi.org/10.1121/1.4 974858.

50. Dizon AE, Lockyer C, Perrin WF, Demaster DP, Sisson J. Rethinking the stock concept: a phylogeographic approach. Conserv Biol. 1992;6(1):24-36. https://doi.org/10.1046/j.1523-1739.1992.610024.x.

51. La Manna G, Rako-Gospić N, Manghi M, Picciulin M, Sarà G. Assessing geographical variation on whistle acoustic structure of three Mediterranean 
populations of common bottlenose dolphin (Tursiops truncatus). Behaviour. 2017;154:583-607.

52. Moura AE, Shreves K, Pilot M, Andrews KR, Moore DM, Kishida T, et al. Phylogenomics of the genus Tursiops and closely related Delphininae reveals extensive reticulation among lineages and provides inference about eco-evolutionary drivers. Mol Phylogenet Evol. 2020;146:106756. https://doi. org/10.1016/j.ympev.2020.106756.

53. Fernandez RM, Santos B, Pierce GJ, Llavona A, Lopez A, Silva MA, et al. Finescale genetic structure of bottlenose dolphins, Tursiopstruncatus, in Atlantic coastal waters of the Iberian Peninsula. Hydrobiologia. 2011;670(1):111-25. https://doi.org/10.1007/s10750-011-0669-5.

54. Natoli A, Birkun A, Aguilar A, Lopez A, Hoelzel AR. Habitat structure and the dispersal of male and female bottlenose dolphins (Tursiops truncatus). ProcBiol Sci. 2005;272(1569):1217-26. https://doi.org/10.1098/rspb.2005.3076.

55. Quérouil S, Freitas L, Cascão I, Alves F, Dinis A, Almeida JR, et al. Molecular insight on the population structure of common and spotted dolphins inhabiting the pelagic waters of the Northeast Atlantic. Mar Biol. 2010 157(11):2567-80. https://doi.org/10.1007/s00227-010-1519-0.

56. Natoli A, Cañadas A, Vaquero C, Politi E, Fernandez-Navarro P, Hoelzel AR. Conservation genetics of the short-beaked common dolphin (Delphinus delphis) in the Mediterranean Sea and in the eastern North Atlantic Ocean. Conserv Genet. 2008;9(6):1479-87. https://doi.org/10.1 007/s10592-007-9481-1.

57. García-Martínez J, Moya A, Raga JA, Latorre A. Genetic differentiation in the striped dolphin Stenella coeruleoalba from European waters according to mitochondrial DNA (mtDNA) restriction analysis. Mol Ecol. 1999;8(6):106973. https://doi.org/10.1046/j.1365-294x.1999.00672.x.

58. Bourret VJR, Macé MRJM, Crouau-Roy B. Genetic variation and population structure of western Mediterranean and northern Atlantic Stenella coeruleoalba populations inferred from microsatellite data. J Mar Biol Ass UK. 2007:87(1):265-9. https://doi.org/10.1017/S0025315407054859.

59. Valsecchi E, Amos W, Raga JA, Podestà M, Sherwin W. The effects of inbreeding on mortality during a morbillivirus outbreak in the Mediterranean striped dolphins (Stenellacoeruleoalba). Anim Conserv. 2004;7: $139-46$

60. Cañadas A, Sagarminaga R, Garia-Tiscar S. Cetacean distribution related with depth and slope in the Mediterranean waters off southern Spain. Deep-Sea Res I. 2002;49(11):2053-73. https://doi.org/10.1016/S0967-0637(02)00123-1.

61. Louis M, Viricel A, Lucas T, Peltier H, Alfonsi E, Berrow S, et al. Habitatdriven population structure of bottlenose dolphins, Tursiops truncatus, in the north-East Atlantic. Mol Ecol. 2014;23(4):857-74. https://doi.org/1 $0.1111 /$ mec. 12653 .

62. Silva MA, Prieto R, Magalhães S, Seabra MI, Santos RS, Hammond PS Ranging patterns of bottlenose dolphins living in oceanic waters: implications for population structure. Mar Biol. 2008;156(2):179-92. https:// doi.org/10.1007/s00227-008-1075-z.

63. Moore DM. An investigation into the environmental drivers of evolution in marine predators. 2020. A thesis presented for the degree of doctor of philosophy, Department of Biosciences, Durham University.

64. Natoli A, Moura A, Hoelzel AR. Conservation genetics of the shortbeaked common dolphin (Delphinus delphis) in the Mediterranean Sea: state of the art and future research. In: Report of the 1st International Workshop Conservation and research networking on short-beaked common dolphin (Delphinus delphis) in the Mediterranean Sea. Ischia Island, Italy. 13-15 April 2016.

65. García-Martínez J, Barrio E, Raga JA, Latorre A. Mitochondrial DNA variability of striped dolphins (Stenella coeruleoalba) in Mediterranean Spanish waters. Mar Mamm Sci. 1995;11(2):183-99. https://doi.org/10.1111/j.1748-7692.1995. tb00517.x.

66. Quérouil S, Silva MA, Cascão I, Magalhaes S, Seabra MI, Machete MA, et al. Why do dolphins form mixed-species associations in the Azores? Ethology 2008;114(12):1183-94. https://doi.org/10.1111/j.1439-0310.2008.01570.x.

67. Ritter F. 21 cetacean species of La Gomera (Canary Islands): possible reasons for an extraordinary species diversity. In: Evans PGH, et al., editors. European research on cetaceans 15, proceedings of the 15th annual conference of the European cetacean society, Rome. Oxford: European Cetacean Society; 2001.

68. Gaspari F, Azzellino A, Airoldi S, Hoelzel AR. Social kin associations and genetic structuring of striped dolphin populations (Stenella coeruleoalba) in the Mediterranean Sea. Mol Ecol. 2007;16(14):2922-33. https://doi.org/1 0.1111/j.1365-294X.2007.03295.X.
69. Caldeira RMA, Reis JC. The Azores confluence zone. Front Mar Sci. 2017;4:37.

70. Mason E, Colas F, Molemaker J, Shchepetkin AF, Troupin C, McWilliams JC, et al. Seasonal variability of the canary current: a numerical study. J Geophys Res. 2011;116:C06001.

71. Coll M, Piroddi C, Steenbeek J, Kaschner K, Ben RaisLasram F, et al. The biodiversity of the Mediterranean Sea: estimates, patterns, and threats. PLoS One. 2010;5(8):e1 1842. https://doi.org/10.1371/journal.pone.0011842.

72. Tintoré J, La Violette PE, Blade I, Cruzado A. A study of an intense density front in the eastern Alboran Sea: the Almerian-Alboranfront. J Phys Oceanogr. 1988;18(10):1384-97. https://doi.org/10.1175/1520-0485(1988)01 8<1384:ASOAID>2.0.CO;2.

73. Aulicino G, Cotroneo Y, Ruiz S, Sánchez Román A, Pascual A, Fusco G, et al. Monitoring the Algerian Basin through glider observations, satellite altimetry and numerical simulations along a SARAL/AltiKa track. J Mar Syst. 2018;179: 55-71. https://doi.org/10.1016/j.jmarsys.2017.11.006.

74. Casella E, Tepsich P, Couvelard X, Caldeira RMA, Schroeder K. Ecosystem dynamics in the Liguro-Provençal Basin: the role of eddies in the biological production. Mediterr Mar Sci. 2014;15(2):274-86. https://doi.org/10.12681/ mms.520.

75. Vetrano A, Napolitano E, lacono R, Schroeder K. Gasparini GP Tyrrhenian Sea circulation and water mass fluxes in spring 2004: observations and model results. J Geophys Res. 2010;115:C06023.

76. Vassallo P, Paoli C, Alessi J, Mandich A, Wurtz M, Fiori C. Seamounts as hotspots of large pelagic aggregations. Mediterr Mar Sci. 2018;19(3):444-58. https://doi.org/10.12681/mms.15546.

77. Connor RC, Wells RS, Mann J, Read AJ. The bottlenose dolphin. In: Mann J, Connor RC, Tyack PL, Whitehead H, editors. Cetacean Societies. Field studies of dolphins and whales. Chicago: University of Chicago Press; 2000. p. 91-125.

78. Breiman L. Random forests. Mach Learn. 2001;45(1):5-32. https://doi.org/10.1 023/A:1010933404324.

79. Parisi I, De Vincenzi G, Torri M, Papale E, Mazzola S, Bonanno A, et al. Underwater vocal complexity of Arctic seal Erignathus barbatus in Kongsforden (Svalbard). J Acoust Soc Am. 2017;142(5):3104-15. https://doi. org/10.1121/1.5010887.

80. Cuttitta A, Torri M, Zarrad R, Zgozi S, Jarboui O, Quinci EM, et al. Linking surface hydrodynamics to planktonic ecosystem: the case study of the ichthyoplanktonic assemblages in the Central Mediterranean Sea. Hydrobiologia. 2018;821(1):191-214. https://doi.org/10.1007/s10750-017-3483-X.

81. Cuttitta A, Bonomo S, Zgozi S, Bonanno A, Patti B, Quinci EM, et al. The influence of physical and biological processes on the ichthyoplankton communities in the Gulf of Sirte (southern Mediterranean Sea). Mar Ecol. 2016;37(4):831-44. https://doi.org/10.1111/maec.12362.

82. Tiedemann M, Fock HO, Döring J, Badji LB, Möllmann C. Water masses and oceanic eddy regulation of larval fish assemblages along the Cape Verde frontal zone. J Mar Syst. 2018;183:42-55. https://doi.org/10.1016/j.jmarsys.201 8.03.004.

83. Breiman L. Bagging predictors. Mach Learn. 1996;24(2):123-40. https://doi. org/10.1007/BF00058655.

84. Liaw A, Wiener M. Classification and regression by randomForest. R News. 2002;2:18-22.

85. Chawla NV, Bowyer KW, Hall LO, Kegelmeyer WP. SMOTE: synthetic minority over-sampling technique. J Artif Intell Res. 2002;16:321-57. https://doi.org/1 0.1613/jair.953.

86. Fernández A, Garcia S, Herrera F, Chawla NV. SMOTE for learning from imbalanced data: progress and challenges, marking the 15-year anniversary. J Artif Intell Res. 2018;61:863-905. https://doi.org/10.1613/jair.1.11192.

87. Branco P, Ribeiro RP, Torgo L. UBL: an R package for utility-based learning, CoRR2016; abs/1604.08079 [cs.MS], URL: http://arxiv.org/abs/1604.08079

88. Samarra FIP, Miller PJO, Deecke VB, Simonis AE. Geographic variation in the time-frequency characteristics of high-frequency whistle sproduced by killer whales (Orcinus orca). Mar Mamm Sci. 2014;31:688-706.

89. Delarue J, Todd SK, Van Parijs SM, Di lorio L. Geographic variation in Northwest Atlantic fin whale (Balaenoptera physalus) song: implications for stock structure assessment. J Acoust Soc Am. 2009;125(3):1774-82. https:// doi.org/10.1121/1.3068454

90. Rendell L, Mesnick SL, Dalebout ML, Burtenshaw J, Whitehead H. Can genetic differences explain vocal dialect variation in sperm whales, Physeter macrocephalus? Behav Genet. 2011;42:332-43.

91. Gridley T, Elwen SH, Rashley G, Badenas Krakauer A, Heiler J. Bottlenose dolphins change their whistling characteristics in relation to vessel 
presence, surface behavior and group composition. Acoust Soc Am. 2017; 27:010030.

92. Brakes P, Carroll EL, Dall SRX, Keith SA, McGregor PK, Mesnick SL, et al. A deepening understanding of animal culture suggests lessons for conservation. Proc Biol Sci. 2021;288:20202718.

93. Fouda L, Wingfield JE, Fandel AD, Garrod A, Hodge KB, Rice AN, et al. Dolphins simplify their vocal calls in response to increased ambient noise. Biol Lett. 2018;14(10):20180484. https://doi.org/10.1098/rsbl.2018.0484.

\section{Publisher's Note}

Springer Nature remains neutral with regard to jurisdictional claims in published maps and institutional affiliations.

- fast, convenient online submission

- thorough peer review by experienced researchers in your field

- rapid publication on acceptance

- support for research data, including large and complex data types

- gold Open Access which fosters wider collaboration and increased citations

- maximum visibility for your research: over $100 \mathrm{M}$ website views per year

At $\mathrm{BMC}$, research is always in progress. 